\title{
The Effect of Whole Body Vibration Exercise on Ankle Joint Spasticity Patients with Chronic Stroke
}

\author{
Yeo-Reum Jo', Mo-Beom Jeong ${ }^{2}$, Dong-Woo Lee ${ }^{3}$ \\ ${ }^{1}$ City Rehabilitation Hospital, Gwangju; ${ }^{2}$ Chung Yeon Oriental Medicine Clinic, Gwangju; ${ }^{3}$ Department of Physical Therapy, Honam University, \\ Gwangju, Korea
}

Purpose: This study aimed to determine the appropriate stimulus strength that could result in a positive effect on the ankle joint spasticity when patients with chronic stroke performed whole body vibration (WBV) exercise.

Methods: Among 72 patients who were diagnosed with stroke at least 6 months ago, those able to perform a half squat pose with ambulation issues due to ankle joint spasticity (modified Ashworth scale, MAS $\geq 2$ ) were included for analysis. Individuals participated in four different frequencies of vertical WBV exercise; $0 \mathrm{~Hz}, 10 \mathrm{~Hz}, 20 \mathrm{~Hz}$, and $30 \mathrm{~Hz}$. Vibration amplitude was 3-4 mm and 5 minutes WBV exercise was performed at each frequency, followed by a measurement after 2-minute rest. We assigned 18 individuals to each frequency and asked them to participate in the WBV exercise once every 3 weeks. The level of spasticity was evaluated by visual analogue scale (VAS) for self-assessment. The myoton PRO was utilized to objectively evaluate the level of spasticity and check the muscle tone and stiffness.

Results: Participants showed $0 \mathrm{~Hz}$ VAS was a significant difference between $20 \mathrm{~Hz}$ application conditions $(\mathrm{p}<0.05)$. Muscle tone was significantly different at $0 \mathrm{~Hz}$ between $20 \mathrm{~Hz}$, and $30 \mathrm{~Hz}(\mathrm{p}<0.05)$, significantly difference at $10 \mathrm{~Hz}$ between $30 \mathrm{~Hz}(\mathrm{p}<0.05)$. Muscle stiffness significantly difference at $0 \mathrm{~Hz}$ between $20 \mathrm{~Hz}$, and $30 \mathrm{~Hz}(\mathrm{p}<0.05)$, significantly difference at $10 \mathrm{~Hz}$ between $20 \mathrm{~Hz}$, and $30 \mathrm{~Hz}(\mathrm{p}<0.05)$.

Conclusion: Findings of this study show that the frequency of more than $20 \mathrm{~Hz}$ was effective in improving the ambulatory ability in patients with chronic stroke. Currently, the effective WBV protocol is limited. Hence, this study was designed to suggest an effective WBV protocol to improve neuromodulation ability for chronic stroke patients.

Keywords: Whole body vibration, Spasticity, Chronic stroke

\section{서 론}

뇌졸중은 국내 사망 원인 3 위를 차지하는 질환으로 과거에 비해 사 망률은 줄었으나 발병률은 증가하고 있는 추세이다. 뇌졸중 후 일반 적으로 $40 \%$ 정도에서 기능적 손상이 남게 되고, $15-30 \%$ 는 심각한 장 애를 얻게 된다.' 이로 인한 스트레스, ${ }^{2}$ 운동능력의 제한, 신체의 장애 및 근력약화, 가동성 저하, 경직, 균형 능력의 문제를 동반하며,4 특정 근육의 약화, 운동협응 장애, 비정상적 시너지 운동을 일으킨다고 하 였다. 운동 조절과 움직임 개시 또한 근육 약화와 근력 저하로 인해 제한된다. ${ }^{6}$

특히 만성 뇌졸중 환자의 경우 다양한 활동 제한으로 인해 불편함 을 호소한다.8. 다양한 활동 영역 중에서도 특히 보행 능력은 일상생 활을 영위하고 다양한 사회적 참여를 위해 필수적인 요소이나 달라
진 보행 능력의 저하로 인해 뇌졸중 환자들이 많은 불편함을 호소해 왔다. 보행 능력의 저하는 뇌졸중 발병 초기 단계부터 빈번하게 나타 나며 영향을 끼치는 다양한 원인 중 하나는 경직(spasticity)이다. 경직 은 일반적으로 속도에 비례하는 근육 신장 반사의 과흥분을 뜻하는 데 힘줄 반사항진과 수동 움직임에 대한 저항 증가, 상위 운동 신경원 의 억제 제어 감소로 인한 근육 긴장 항진이 특징이다.10 또 뇌졸중, 뇌 성마비, 다발성 경화증, 척수 손상 및 기타 중추신경계 병변 후 가장 흔히 발생하는 것으로 알려진 증상이기도 하다. 실제로 척수 또는 대 뇌 병변이 있는 많은 환자들이 경직성 운동 장애를 갖고 있다. 지속적 인 경직으로 관절 위치의 제한," 경직 근육과 관절 주변 결합 조직의 변화로 연부 조직이 짧아져 능동적, 수동적 관절 가동성, 하지의 수의 적 움직임, 보행 안정성, 일상생활 활동을 제한한다.12 이러한 경직에 대한 주요 접근법은 보존적 치료와 외과적 개입이 있다. 물리치료 영 
역에서는 기존의 보존적 치료인 근육 스트레칭, 초음파 치료, 열 치 료, 전기 자극 등 ${ }^{13}$ 의 다양한 방향으로 접근하였다. 최근에는 뇌졸중 환자의 경직 완화를 위한 새로운 치료 방법으로 진동 자극이 제안되 고 있다. ${ }^{14}$

그 중 전신 진동 운동(whole-body vibration exercise)은 일반인의 신 경근 훈련으로 사용되어 오다가, ${ }^{15}$ 최근에는 전신 진동 운동을 많은 임상가들이 재활 목적으로 사용하고 있는 추세이다. ${ }^{16}$ 운동의 수직 정현파 진동을 특징으로 하는 기계적 자극은 진동 플랫폼을 사용하 여 발에서 다른 신체부위로 전달된다. ${ }^{77}$ 전신 진동 운동은 기본적으 로 기계적 진동을 인체 근복부에 직접적으로 가했을때 반사적 수축 을 유발한다는 긴장성 진동 반사(tonic vibration reflex)에 이론적 근거 를 두는데, ${ }^{18}$ 인체가 플랫폼 위에 서 있을 때 플랫폼이 반복적으로 아 래로 떨어짐과 동시에 다음 상향 이동을 시작하는데 이러한 충격이 발생할 때마다 근육과 힘줄은 급격하게 늘어난다. ${ }^{19}$ 인체는 근육과 힘줄을 통해 진동을 인지하고 진동을 완충시키기 위한 적응 반응을 보이게 되며 이를 통해 긴장성 진동 반사, 즉 반사적 근수축을 일으켜 근신경계의 기능 향상을 일으킨다. 또 근육의 경직을 감소시켜 능동 적, 수동적 가동 범위를 늘리고 보행률, 보행 속도 등의 보행 능력을 증진 시킨다고 보고하였다. ${ }^{2}$

과거의 연구에서는 진동이 대부분 인체에 부정적인 영향을 미치 는 것으로 설명되어 왔다. ${ }^{20}$ 기계장치 등에서 발생하는 물리적 충격 및 진동 자극은 매스꺼움, 구토, 멀미, 현기증을 야기하며 반복적으 로 장시간 노출될 경우 생체조직 손상이나 허리, 무릎, 어깨, 목, 손목 에 통증 및 부종 등의 근골격계 질환을 유발시키는 원인으로 알려져 있다. ${ }^{21}$ 그러나 최근에는 전신 진동 운동의 진동 강도를 적절히 조절 하여 인체가 적응할 수 있는 범위 내에서 제공하여 근신경계의 다양 한 기능 향상을 위한 훈련 방법으로 활용되고 있다. ${ }^{22}$ 또한 전신 진동 운동은 특별한 부작용이 없고 큰 어려움이 없으며 운동 방법을 익히 기에 어렵지 않기 때문에 고령자와 체력 수준이 낮은 다양한 환자에 게도 적용될 수 있다. ${ }^{23}$ 그러나 이런 다양한 장점들이 있지만 운동 전 신 진동 운동에 대한 안전하고 효과적이며 적절한 프로토콜에 대한 지식은 부족한 실정이다. 따라서 본 연구는 전신 진동 운동이 만성 뇌 졸중 환자의 발목관절 경직에 가장 효과적인 영향을 미치는 빈도수 를 알아보고자 한다.

\section{연구 방법}

\section{1. 연구대상}

본 연구는 2017년 9월 11일부터 30일까지 광주 광역시 C 재활의학과 요양 병원에 입원한 뇌졸중 환자 72 명을 대상으로 하였다. 신경학적 회복에 의한 치료 효과를 배제하기 위하여 초기 기능적 회복 기간인 6개월이 지났으며 전신 진동 훈련 시 하프 스쿼트 자세 $\left(30^{\circ}\right.$ 의 무릎 굽 히기)가 가능한 환자들을 대상으로 선정하였다. 선정기준은 1) 본 병 원에서 뇌졸중을 진단받은 자, 2) 발병 후 6개월 이상 경과한 자, 3) mini-mental state examination-Korean (MMSE-K) 점수가 24점 이상인 자로 의사소통이 가능한 자, 4) 전신 진동 운동에 영향을 줄 수 있는 골절이나 기형 등 정형외과적 문제가 없는 자, 5) 시각 및 청각, 고유수 용성 감각에 이상이 없는 자, 6) 임신, 신장결석, 인공심장, 혈전 등의 질환이 없어 진동 운동을 할 수 있는 자, 7) 보조도구를 이용하거나 독립적으로 $10 \mathrm{~m}$ 보행할 수 있는 자, 8) 발목관절 경직(modified Ashworth scale, MAS $\geq 2$ )이 있는 자로서 본 연구를 실시하기 전에 연구 목 적과 방법에 대하여 충분히 설명한 후 자발적인 동의를 얻은 후에 연 구를 실시했다. 총 74명의 대상자를 모집하였으나 실험 중 퇴원으로 인하여 2 명이 중도에 탈락하여 제외하고 본 연구에 참여한 대상자 총 72 명이 전신 진동 운동을 수행하였다. $0,10,20,30 \mathrm{~Hz}$ 네 가지 빈도 수에 각 18 명씩 모집순서에 따라 무작위로 배정되었다. 대상자 중 남 자는 70 명, 여자는 2 명이었고 뇌경색이 28 명, 뇌출혈이 44 명이었고 우 측 마비는 24 명, 좌측 마비는 48 명이었다. 대상자의 일반적인 특성에 대한 각 그룹 간 유의한차이는 없었다( $\mathrm{p}>0.05)$ (Table 1).

\section{2. 실험방법}

\section{1) 중재방법}

총 72 명의 실험 참가자들은 $0,10,20,30 \mathrm{~Hz}$ 네 가지 빈도수의 수직 전 신 진동 운동에 참여했다. 각 빈도수마다 5 분간 전신 진동 운동을 수 행하고 2 분 휴식 후 측정하였다. 실험에 참가하게 된 최종 대상자들 은 진동운동기 위에서 직립자세를 취하게 될 경우 진동 운동이 하지 에 집중적으로 전달되지 못하므로 하지에 보다 집중적인 진동 자극 을 유발시키기 위해 선행연구24-26와 유사한 하프 스쿼트 자세를 취하 였다. 5 분간 하프 스쿼트 자세를 안정적으로 유지하기 위해 보바스

Table 1. The general characteristics of subject

$(n=72)$

\begin{tabular}{lcccccc}
\hline & $0 \mathrm{~Hz}(\mathrm{n}=18)$ & $10 \mathrm{~Hz}(\mathrm{n}=18)$ & $20 \mathrm{~Hz}(\mathrm{n}=18)$ & $30 \mathrm{~Hz}(\mathrm{n}=18)$ & $\mathrm{F}$ & $\mathrm{p}$ \\
\hline Age (year) & $55.44 \pm 5.99$ & $57.00 \pm 6.68$ & $54.83 \pm 6.17$ & $57.17 \pm 3.94$ & 0.710 & 0.549 \\
Height (cm) & $169.50 \pm 4.47$ & $169.89 \pm 3.93$ & $169.94 \pm 4.50$ & $172.00 \pm 5.97$ & 1.002 & 0.769 \\
Weight (kg) & $66.89 \pm 10.06$ & $69.39 \pm 8.81$ & $68.67 \pm 7.56$ & $66.83 \pm 8.88$ & 0.378 & 0.769 \\
Onset time (month) & $67.89 \pm 35.34$ & $50.59 \pm 30.13$ & $48.22 \pm 41.65$ & $38.33 \pm 29.18$ & 2.291 & 0.086 \\
\hline
\end{tabular}

$\mathrm{M} \pm \mathrm{SD}:$ Mean \pm standard deviation. 
테이블 높이를 높여 궁둥뼈 결절 밑에 위치시켜 엉덩이를 보조하도 록 하였다. ${ }^{24}$ 참가자들에게는 무릎의 각도를 $30^{\circ}$ 로 유지하고 양 발에 고르게 체중을 분배하도록 요청하였다. 진동폭은 $3-4 \mathrm{~mm}$ 로 적용했 다. 18 명의 실험 참가자들을 각각의 빈도수에 배정하고, 총 3 주간 모 집하여 1 회 전신 진동 운동에 참여시켰다. 전신 진동 운동 수행 시 안 전을 위해 물리치료사가감독하였다.

\section{2) 측정도구}

(1) 경직 수준 자가 평가

경직의 수준을 평가하기 위하여 시각적 상사 척도(visual analogue scale, VAS)를 사용하였다. 시각적 상사 척도는 대상자의 경직 정도를 주관적으로 평가하는 하나의 방법이다. 대상자를 다른 대상자와 비 교할 수는 없지만 동일한 대상자에 대해서는 경직 정도의 변화를 상 당히 정확하게 평가할 수 있다. 시각적 상사 척도는 0 에서 10 까지의 범 위를 가지며 0 은 경직이 없는 상태를 나타내고, 10 은 보행을 방해하 는 최대 경직 강도를 의미한다. ${ }^{27}$ 본 연구에서는 대상자에게 스스로 느끼는 경직의 정도를 표시하도록 하였다.

\section{(2) 발목관절 경직 평가(근긴장도\&근경도)}

대상자의 경직 수준을 객관적으로 평가하기 위해 Myoton PRO (MyotonAS, Estonia, 2013)를 사용하였다. Myoton PRO는 비침습적인 방법 으로 조직의 생체 역학적 특성을 빠르고 편리하게 측정할 수 있다. ${ }^{28}$ 근전도와는 다르게 근육의 이완 시에도 측정이 가능한 장점이 있으 며, 근수축과 근이완 시에 경직 상태를 객관적인 수치로 제공하도록 되어 있다. 먼저 탐침(probe)을 사용하여 연부 조직에 일정한 압력을 제공한다. 그리고 신체 내부의 연부 조직에 진동을 유도하여 자연스 럽게 처음 형태로 회복되는 것을 측정한다. 이완 시의 근긴장도는 $\mathrm{Hz}$ 로 제공되며 근수축 시 외력에 모양이 바뀌지 않도록 유지하는 근경 도(muscle stiffness)와 외력에 의해 모양이 바뀐 후 처음 모양으로 돌 아오는 능력인 탄성(elasticity)도 함께 표기된다. Myoton PRO에 대한 선행 연구에서 평가자 내 신뢰도에서의 상관계수는 0.94-0.99로 나타 났다. ${ }^{29}$ 평가는 한 명의 연구자가 모두 수행하였다.

\section{3) 분석방법}

이 연구의 모든 자료는 SPSS software (ver. 21.0 for Windows, SPSS, Chicago, IL, USA)를 사용하여 분석했다. 대상자의 일반적 특성은 기술 통계로 결과를 서술하였고, 각 조건에서의 변화를 보기 위하여 일원 배치 분산분석(one-way ANOVA)을 사용하여 분석하였다. 조건 간차 이의 유의성 검정을 위하여 사후 검정으로 Tukey honestly significant difference $(\mathrm{HSD})$ 검정을 실시했다. 자료의 통계 분석에서 모든 통계학 적 유의 수준은 $\alpha=0.05$ 로 정했다.

\section{결 과}

\section{1. 경직 수준 자가 평가 변화}

전신 진동 운동 전과 후 대상자들의 VAS 점수 변화량의 차이를 나타 내었다(Figure 1). 운동 적용 후 대상자들의 VAS 점수 변화량은 $0 \mathrm{~Hz}$ 에 서 - $0.67 \pm 0.48$ 점, $10 \mathrm{~Hz}$ 적용 후 $-1.56 \pm 1.54$ 점, $20 \mathrm{~Hz}$ 적용 후 $-1.28 \pm 1.07$ 점, $30 \mathrm{~Hz}$ 적용 후 $-1.28 \pm 1.07$ 점으로, 전신 진동 운동 후에 점수가 감소 하는 양상을 보이며 통계적으로 유의한 변화가 있었다 $(\mathrm{p}<0.05)$. 사후 분석 결과 전신 진동 운동 $0 \mathrm{~Hz}$ 조건은 $20 \mathrm{~Hz}$ 적용 조건과 유의한 차 이가 있었다 $(\mathrm{p}<0.05)$. 그러나 $0 \mathrm{~Hz}$ 와 $10,30 \mathrm{~Hz}$ 적용 조건 사이에는 유 의한 차이가 없었고, $10,20,30 \mathrm{~Hz}$ 적용 조건 사이에서도 유의한 차이 가 없었다.

\section{2. 발목관절 경직 측정치 변화}

1) 근긴장도 $(\mathrm{Hz})$ 의 변화

본연의 진동을 나타내며 수의적인 동작 없이 수동적 움직임 혹은 쉬

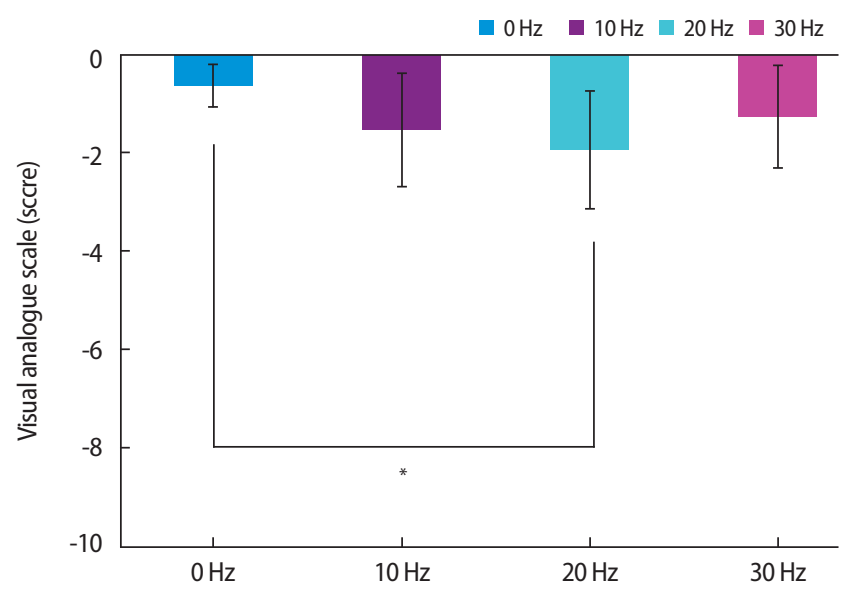

Figure 1. The compared of spasticity was evaluated by visual analogue scale for self-assessment $(* \mathrm{p}<0.05)$.

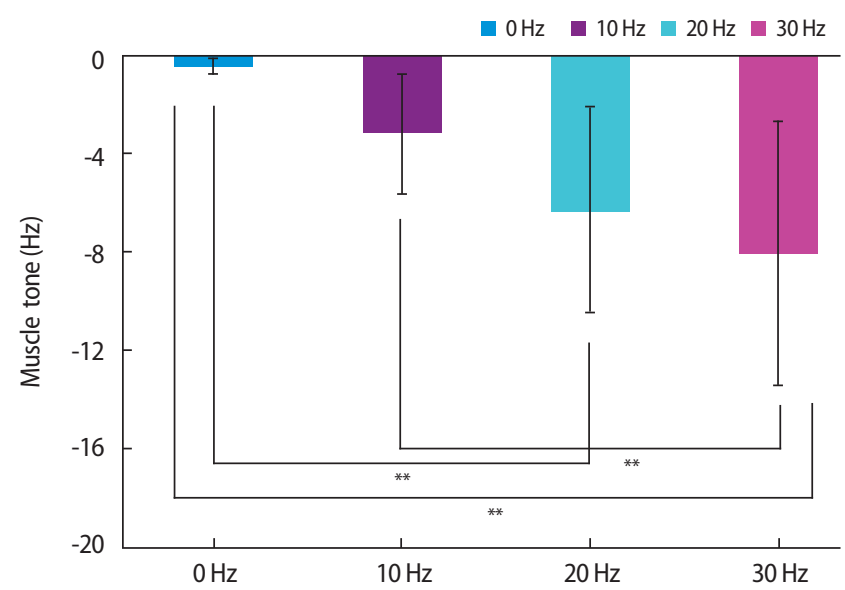

Figure 2. The compared of change in muscle tone per $\mathrm{Hz}\left({ }^{* *} \mathrm{p}<0.01\right)$. 


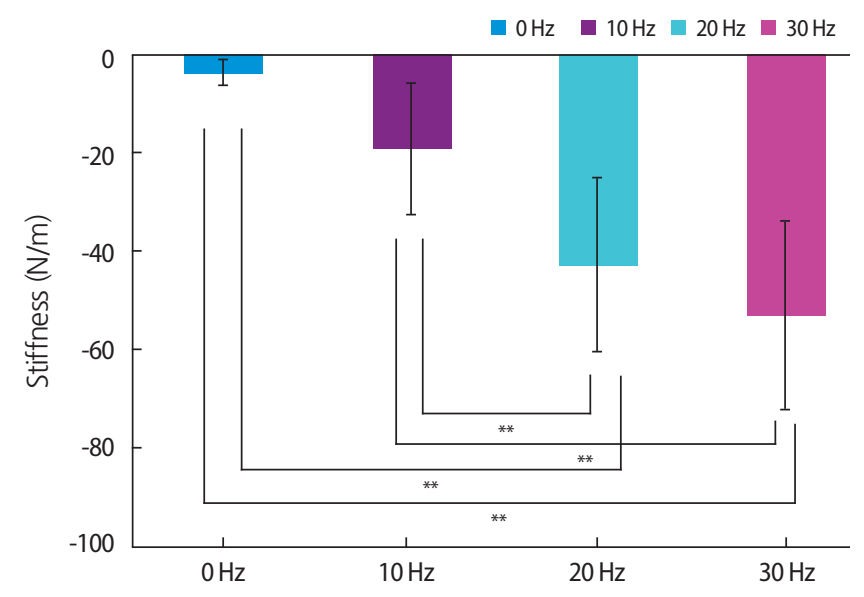

Figure 3. The compared of change in stiffness per $\mathrm{Hz}\left({ }^{* *} \mathrm{p}<0.01\right)$.

고 있는 상태에서의 근긴장도(muscle tone)의 변화량 차이를 나타내었 다(Figure 2). 운동 적용 후 대상자들의 근긴장도인 진동 주파수의 변화 량은 $0 \mathrm{~Hz}$ 조건에서 $-0.45 \pm 0.39 \mathrm{~Hz}, 10 \mathrm{~Hz}$ 적용 후 $-3.16 \pm 2.48 \mathrm{~Hz}, 20 \mathrm{~Hz}$ 적용 후 $-6.33 \pm 4.26 \mathrm{~Hz}, 30 \mathrm{~Hz}$ 적용 후 $-8.07 \pm 5.46 \mathrm{~Hz}$ 로 전신 진동 운동 후에 진동 주파수의 변화량이 증가하는 양상을 보이며, 진동 주파수의 변화는 통계적으로 유의한 차이가 있었다 $(\mathrm{p}<0.05)$. 사후 분석 결과 전 신 진동 운동 $0 \mathrm{~Hz}$ 조건은 $20 \mathrm{~Hz}, 30 \mathrm{~Hz}$ 적용 조건 사이에서 모두와 유의 하였으나 $(\mathrm{p}<0.05), 10 \mathrm{~Hz}$ 조건 사이에서는 유의한 차이가 없었다. $10 \mathrm{~Hz}$ 적용 조건은 $30 \mathrm{~Hz}$ 조건 사이에서 유의하였으나 $(\mathrm{p}<0.05), 20 \mathrm{~Hz}$ 적용 조 건 사이에서는 유의한 차이가 없었다. $20 \mathrm{~Hz}$ 조건과 $30 \mathrm{~Hz}$ 적용 조건 사 이에서도 유의한차이가 없었다.

\section{2) 근경도(muscle stiffness)의 변화}

근수축 시의 저항이나 외력에 의해 처음 모양이 바뀌지 않도록 유지 하는 근육의 생역학적 특성인 근경도의 변화량 차이는 나타내었다 (Figure 3). 운동 적용 후 대상자들의 근경도 변화량은 $0 \mathrm{~Hz}$ 에서 $-3.47 \pm$ $2.72 \mathrm{~N} / \mathrm{m}, 10 \mathrm{~Hz}$ 적용 후 $-18.99 \pm 13.85 \mathrm{~N} / \mathrm{m}, 20 \mathrm{~Hz}$ 적용 후 $-42.72 \pm 25.71$ $\mathrm{N} / \mathrm{m}, 30 \mathrm{~Hz}$ 적용 후 $-52.87 \pm 29.62 \mathrm{~N} / \mathrm{m}$ 로 전신 진동 운동 후에 근경도 의 변화량이 증가하는 양상을 보이며, 전신 진동 운동의 빈도수가 높 아질수록 근경도가 감소하였다. 근경도의 변화는 통계적으로 유의한 차이가 있었다 $(\mathrm{p}<0.05)$. 사후 분석 결과 전신 진동 운동 $0 \mathrm{~Hz}$ 조건은 $20 \mathrm{~Hz}, 30 \mathrm{~Hz}$ 적용 조건 사이에서 모두와 유의하였으나 $(\mathrm{p}<0.05), 10 \mathrm{~Hz}$ 조건 사이에서는 유의한 차이가 없었다. $10 \mathrm{~Hz}$ 적용 조건은 $20 \mathrm{~Hz}, 30$ $\mathrm{Hz}$ 조건 사이에서 유의하였으나 $(\mathrm{p}<0.05), 20 \mathrm{~Hz}$ 조건과 $30 \mathrm{~Hz}$ 적용 조 건 사이에서는 유의한 차이가 없었다.
고 찰

본 연구는 72 명의 만성 뇌졸중 환자를 대상으로 전신 진동 운동의 빈 도수가 발목관절의 경직수준에 미치는 영향을 알아보기 위하여 시 행되었다. 효과의 차이에 따라 전신 진동 운동이 인체에 미치는 부정 적 영향이 최소화되고 긍정적인 영향이 있는 진동 주파수를 알아보 고자 하였다. 근긴장도는 전신 진동 운동 전후 통계적으로 유의한 차 이가 있었다. $0 \mathrm{~Hz}$ 조건과 $20 \mathrm{~Hz}, 30 \mathrm{~Hz}$ 조건 사이에서, $10 \mathrm{~Hz}$ 와 $30 \mathrm{~Hz}$ 조 건 사이에서의 변화량차이에서도 유의하게 증가하였다 $(\mathrm{p}<0.05)$. 근경 도의 경우에도 통계적으로 유의한 차이를 볼 수 있었는데 $0 \mathrm{~Hz}$ 조건 과 $20 \mathrm{~Hz}, 30 \mathrm{~Hz}$ 조건 사이에서, $10 \mathrm{~Hz}$ 조건과 $20 \mathrm{~Hz}, 30 \mathrm{~Hz}$ 조건 사이에 서도 변화량 차이가 유의하게 증가하는 결과를 볼 수 있었다 $(\mathrm{p}<0.05)$. 이러한 경직 측정 결과에서 공통적으로 전신 진동 운동의 빈도수가 높아질수록 경직이 감소하는 것을 볼 수 있는데, 이는 $20 \mathrm{~Hz}$ 이상의 전신 진동 운동 빈도수가 뇌졸중 편마비 환자의 신경 조절 능력을 개 선시킨다는 선행연구와 비슷한 결과를 나타내고 있다. ${ }^{30}$ 또한 전신 진 동 운동을 만성 뇌졸중 환자에게 단기간 적용했을 때 발목관절 경직 을 감소시킬 수 있어 이동 능력 증진에 효과적이라고 보고한 선행연 구와도 같은 결과를 나타낸다. ${ }^{44}$ 또 Pang 등 ${ }^{31}$ 은 82 명의 뇌졸중 환자에 게 전신 진동 운동을 적용하여 무릎과 발목관절의 경직에 유의한 차 이가 발생했다고 보고했다. Miyara 등 12 은 뇌졸중 환자에게 $30 \mathrm{~Hz}$ 의 전신 진동 운동을 뒤넙다리근과, 장딴지근, 가자미근에 5 분간 적용한 결과 경직이 감소되었다고 하였다. 그 외에 다발성 경화증, 뇌성마비 등의 다른 신경계 환자를 대상으로 한 선행 연구에서도 유의한 결과 가 나타났다. Schyns 등 ${ }^{32}$ 은 다발성 경화증 환자를 대상으로 4주간 전 신 진동 운동을 적용한 결과 경직에서 유의한 변화가 있었다고 보고 했다. 또한 Cheng 등 ${ }^{33}$ 은 4 주간 뇌성마비 아동에게 전신 진동 운동을 적용한 결과 넙다리네갈래근의 경직 감소가 대조군에 비해 크게 변 화하였다고 보고했다. 이와 관련되어 경직 자가 평가 부분에서도 유 의한 감소를 볼 수 있었다. $0 \mathrm{~Hz}$ 조건과 $20 \mathrm{~Hz}$ 조건 사이에서 유의한 변화를 볼수 있었고 $(\mathrm{p}<0.05), 30 \mathrm{~Hz}$ 조건에서는 $20 \mathrm{~Hz}$ 에 비해 경직 자 가 평가 점수가 증가한 것을 볼 수 있었다. 이것은 대상자들이 $30 \mathrm{~Hz}$ 에서 느끼는 실제 진동 강도가 강하여 보바스 테이블에 앉아 있음에 도 불구하고 자세유지의 어려움과 미끄러져 낙상에 대한 공포심으 로 실상 체감하기에 불편함이 있어 만족도가 상대적으로 떨어졌기 때문으로 보인다.

전신 진동 운동은 연접전억제(presynaptic inhibition)를 촉진시켜 운동 신경 전달을 조절한다. ${ }^{34}$ 근육에 직접 전달되는 진동 자극이 연 접 이전의 Ia 구심성 억제를 유도하여 신경전달 물질 방출을 감소시 키고 알파운동신경에 대한 Ia 구심성 영향을 저하시킨다. 또한 구심 성 감각 신경은 척수 전각의 Ia 억제성 개재신경원(Ia inhibitory inter- 
neuron)을 통해 길항근에 전달되는 알파운동신경원의 흥분성을 억 제시켜 길항근을 이완시키는 상호억제 반응(reciprocal inhibition)이 일어난다. Ia 억제성 개재신경원은 하행경로(descending pathway)로 부 터 흥분과 억제신호를 받게 되고 알파운동신경원과 감마운동신경 원은 고위 중추(higher center)로부터 적당한 근긴장도를 유지하도록 조절된다. ${ }^{35}$ 이러한 신경 생리학적 억제 기전들과, 근육의 반사작용과 기계적 성질에 대한 전신 진동의 영향은 경직이 있는 중추 신경계 환 자들에게 긍정적 영향을 미칠 수 있다. ${ }^{36}$ 또한 경직으로 인한 다양한 2 차적 문제 중 기능적인 이동 능력과 활동과 참여 부분에도 영향을 미친다. ${ }^{37}$

본 연구는 전신 진동 적용 후 즉각적인 효과를 확인하기 위하여 단 기간 적용하였다. 전신 진동 운동의 단기간 적용 시 운동 단위는 즉각 적으로 평소 상태나 수의적 근수축보다 더 많은 운동 단위나 근섬유 를 활성화시킨다. ${ }^{38}$ 그래서 근육을 더욱 신속하고 효율적으로 사용할 수 있어 적은 근피로로 더 많은 힘을 생산할 수 있다. Da silva 등 ${ }^{39}$ 의 연구에 따르면 전신 진동 운동을 적용한 후 적절한 휴식시간은 단기 간 전신 진동 운동을 적용했을 경우 2 분, 장기간 연구에서는 누적된 자극으로 인해 1 분의 휴식시간이 효과적인 근 기능 향상을 보였다고 하였다. 이에 기초하여 본 연구도 매 조건의 전신 진동 운동 적용 후2 분의 휴식시간을 제공 후 평가했다.

본 연구는 대상자에게 전신 진동 운동을 단기간으로 적용하였을 때 근긴장도, 근경도에 있어서는 $20 \mathrm{~Hz}$ 이상이 유의한 차이를 보였지 만자가 경직수준 평가에서는 $30 \mathrm{~Hz}$ 이상은 운동 시 대상자에게 불편 함을 줄 수 있는 강도로 사료된다. 보바스 테이블에 완전한 체중지지 를 실시하게 되는 대상작용을 최대한 배제하고 치료 효과에 포커스 를 맞췄다. 그러나 대상자 수가 적고 병원에 입원중인 환자 중에서 연 구 조건에 충족하는 일부를 대상자로 선정하였기에 만성 뇌졸중 환 자 전체에 일반화하기 어렵고 장기간 전신 진동 운동을 적용하였을 때 대상자의 발목관절 경직과 보행 능력에 어떠한 영향을 미치는지 알 수 없다는 제한점이 있다. 또한 실험을 진행하면서 연구대상자의 모집 시 발병기간이 달라 중재프로그램에 대한 종속변인의 임상적인 효과를 제시하기에는 어려움이 있다. 앞으로 $10,20,30 \mathrm{~Hz}$ 보다 다양 한 기간과 더 좁은 범위의 빈도수, 다양한 진폭, 진동 방향을 적용하 여 체계적이고 효율적이며 선택적으로 적용할 수 있는 일반화된 프 로토콜에 대한 연구가 계속되어야 할 것이다.

\section{감사의 글}

2018년 호남대학교 조여름 석사학위 논문을 수정 보완한 것이다.

\section{참고문헌}

1. Duncan PW, Horner RD, Reker DM et al. Adherence to post acute rehabilitation guidelines is associated with functional recovery in stroke. Stroke. 2002;33(1):167-78.

2. Kim JW, Park MC. A study on the impacts of stroke patients disease-related characteristics on depression and family support. J Kor Phys Ther. 2017;29(2):62-8.

3. Yu KH, Kang KY. Functional electrical stimulation with augmented feedback training improves gait and functional performance in individuals with chronic stroke: a randomized controlled trial. J Kor Phys Ther. 2017;29(2):74-9.

4. Song GB, Heo JY. The effects of bridge exercise with abdominal drawingin on balance in patients with stroke. J Kor Phys Ther. 2016;28(1):1-7.

5. Kim P, Warren S, Madill H et al. Quality of life of stroke survivors. Qual Life Res. 1999;8(4):293-301.

6. Shin HK, Lee DH. Comparison of the symmetry of buttock pressure during simulated driving between heathy adults and patients with stroke. J Kor Phys Ther. 2017;29(4):218-22.

7. Lee NK, Kim YM, Kim K. Influence of unilateral muscle fatigue in knee and ankle joint on balance and gait in healthy adults. J Kor Phys Ther. 2017;29(1):39-43.

8. Gu JS, Choi SJ, Choi HS et al. Effects of pelvic tilt training using inclinometer on joint position sense and postural alignment in patients with chronic stroke. J Kor Phys Ther. 2016;28(1):33-8.

9. Park JH, Chung Y. A comparison of underwater gait training with additional weight application and over-ground gait training to improve balance and lower extremity strength in persons with stroke. J Kor Phys Ther. 2017;29(2):101-7.

10. Feldman RG, Young RR, Koella WP. Spasticity, disordered motor control. Chicago, Year Book Medical, 1980.

11. Jeong MB, Kim JY, Lee DW. Comparison of the effectiveness of sling exercise and McKenzie exercise in patients with acute cervical whiplash associated disorder following rear-end collision. J Kor Phys Ther. 2016; 28(5):314-20.

12. Miyara K, Matsumoto S, Uema T et al. Feasibility of using whole body vibration as a means for controlling spasticity in post-stroke patients: A pilot study. Complement Ther Clin Pract. 2014;20(1):70-3.

13. Mesci N, Ozdemir F, Kabayel DD et al. The effects of neuromuscular electrical stimulation on clinical improvement in hemiplegic lower extremity rehabilitation in chronic stroke: A single-blind, randomised, controlled trial. Disabil Rehabil. 2009;31(24):2047-54.

14. Noma T, Matsumoto S, Etoh S et al. Anti-spastic effects of the direct application of vibratory stimuli to the spastic muscles of hemiplegic limbs in post- stroke patients. Brain Inj. 2009;23(7-8):623-31.

15. Rehn B, Lidström J, Skoglund J et al. Effects on leg muscular performance from whole-body vibration exercise: A systematic review. Scand J Med Sci Sports. 2007;17(1):2-11.

16. Bogaerts A, Delecluse C, Claessens AL et al. Impact of whole-body vibration training versus fitness training on muscle strength and muscle mass in older men: A 1-year randomized controlled trial. J Gerontol A Biol Sci Med Sci. 2007;62(6):630-5.

17. Albasini A, Krause M, Rembitzki I. Using whole body vibration in physical therapy and sport E-Book: Clinical practice and treatment exercises. 
Churchill Livingstone, Elsevier Health Sciences, 2010.

18. Hagbarth KE, Eklund G. Tonic vibration reflexes (TVR) in spasticity. Brain Res. 1966;2(2):201-3.

19. Cochrane DJ, Loram ID, Stannard SR et al. Changes in joint angle, muscle- tendon complex length, muscle contractile tissue displacement, and modulation of EMG activity during acute whole-body vibration. Muscle Nerve. 2009;40(3):420-9.

20. Palmer KT, Griffin MJ, Bendall H et al. Prevalence and pattern of occupational exposure to whole body vibration in Great Britain: Findings from a national survey. Occup Environ Med. 2000;57(4):229-36.

21. Min JY, Bea JJ. Study on the effects of vibration exercise for the human body. KSME. 2009;11:2672-7.

22. In TS, Song CH. The effects of whole body vibration on knee extensor strength, and balance and walking ability with chronic stroke. J Korean Soc of Phys Med. 2010;5(4):675-83.

23. Cardinale M, Wakeling J. Whole body vibration exercise: Are vibrations good for you? Br J Sports Med. 2005;39(9):585-9.

24. Chan KS, Liu CW, Chen TW et al. Effects of a single session of whole body vibration on ankle plantarflexion spasticity and gait performance in patients with chronic stroke: A randomized controlled trial. Clin Rehabil. 2012;26(12):1087-95.

25. Marin PJ, Santos-Lozano A, Santin-Medeiros F et al. Whole-body vibration increases upper and lower body muscle activity in older adults: Potential use of vibration accessories. J Electromyogr Kinesiol. 2012; 22(3):456-62.

26. Sayenko DG, Masani K, Alizadeh-Meghrazi M et al. Acute effects of whole body vibration during passive standing on soleus H-reflex in subjects with and without spinal cord injury. Neurosci Lett. 2010;482(1):6670.

27. Wu CL, Huang MH, Lee CL et al. Effect on spasticity after performance of dynamic-repeated-passive ankle joint motion exercise in chronic stroke patients. Kaohsiung J Med Sci. 2006;22(12):610-7.

28. Bailey L, Samuel D, Warner M et al. Parameters representing muscle tone, elasticity and stiffness of biceps brachii in healthy older males: symmetry and within-session reliability using the MyotonPRO. J Neurol Disord. 2013;1(1):1-7.

29. Agyapong-Badu S, Aird L, Bailey L et al. Interrater reliability of muscle tone, stiffness and elasticity measurements of rectus femorisand biceps brachii in healthy young and older males. Work Pap Health Sci. 2013; 1(4):1-11.

30. Choi DS. Effects of vibration stimulation intensity during whole-body vibration exercise on soleus H-reflex in hemiplegic stroke patients. Asian J Kinesiol. 2014;16(4):83-92.

31. Pang M, Lau R, Yip S. The effects of whole-body vibration therapy on bone turnover, muscle strength, motor function, and spasticity in chronic stroke: A randomized controlled trial. Eur J Phys Rehabil Med. 2013; 49(4):439-50.

32. Schyns F, Paul L, Finlay K et al. Vibration therapy in multiple sclerosis: A pilot study exploring its effects on tone, muscle force, sensation and functional performance. Clin Rehabil. 2009;23(9):771-81.

33. Cheng HY, Ju YY, Chen CL et al. Effects of whole body vibration on spasticity and lower extremity function in children with cerebral palsy. Hum Mov Sci. 2015;39:65-72.

34. Nielsen J, Petersen N, Crone C. Changes in transmission across synapses of Ia afferents in spastic patients. Brain. 1995;118(4):995-1004.

35. Delwaide PJ. Human reflex studies for understanding the motor system. Phys Med Rehabil Clin N Am. 1993;4:669-86.

36. Lance J. Disordered muscle tone and movement. Clin Exp Neurol. 1981;18:27-35.

37. Lieber RL, Steinman S, Barash IA et al. Structural and functional changes in spastic skeletal muscle. Muscle Nerve. 2004;29(5):615-27.

38. Bosco C, Iacovelli M, Tsarpela $\mathrm{O}$ et al. Hormonal responses to wholebody vibration in men. Eur J Appl Physiol. 2000;81(6):449-54.

39. Da Silva-Grigoletto ME, Vaamonde DM, Castillo E et al. Acute and cumulative effects of different times of recovery from whole body vibration exposure on muscle performance. J Strength Cond Res. 2009;23(7):2073-82. 